\title{
Heterologous expression and enzymatic characterization of $\beta$-glucosidase from the drywood-eating termite, Neotermes koshunensis
}

\author{
Jinfeng Ni, ${ }^{1,2}$ Gaku Tokuda, $^{1,3}$ Motomi Takehara ${ }^{1}$ and Hirofumi Watanabe ${ }^{1, *}$ \\ ${ }^{1}$ National Institute of Agrobiological Sciences; Tsukuba, Ibaraki 305-8634, Japan \\ ${ }^{2}$ State Key Laboratory of Microbial Technology, Shandong University; 27 Shandanan Road, Jinan, Shangdong 250100, P. R. China \\ ${ }^{3}$ Center of Molecular Biosciences (COMB), University of the Ryukyus; Nishihara, Okinawa 903-0213, Japan
}

(Received 23 January 2007; Accepted 24 April 2007)

\begin{abstract}
A $\beta$-glucosidase cDNA from the termite, Neotermes koshunensis, was successfully overexpressed in Escherichia coli, and the product was purified to homogeneity by affinity purification against His-tags. The molecular weight of the recombinant enzyme was $60 \mathrm{kDa}$. The expressed $\beta$-glucosidase preferentially hydrolyzed laminaribiose and cellobiose rather than synthetic substrates such as $p$-nitrophenolic compounds. The $K_{\mathrm{m}}$ value of cellobiose was $3.8 \mathrm{~mm}$ and $V_{\max }$ was $220 \mathrm{U}(\mu \mathrm{mol}$ of glucose $/ \mathrm{min}) / \mathrm{mg}$. The optimum $\mathrm{pH}$ and thermostability were 5.0 and $45^{\circ} \mathrm{C}$, respectively. These enzymatic characters are mostly consistent with the partially-purified $\beta$-glucosidase from the salivary glands of $N$. koshunensis. However, the specific activity of the recombinant enzyme was $156.7 \mathrm{U} / \mathrm{mg}$, which is almost 3 -folds of that of the partially purified $\beta$-glucosidase of $N$. koshunensis. Owing to the successful expression of the termite $\beta$-glucosidase in $E$. coli, it may provide an opportunity of termite $\beta$-glucosidase for further improvement of the enzymatic properties for potential industrial applications with the aid of bioengineering.
\end{abstract}

Key words: Termite; Neotermes koshunensis; $\beta$-glucosidase; heterologous expression

\section{INTRODUCTION}

With a shortage of fossil fuel, utilization of cellulose as regenerated energy has attracted general interest, and a broader range of cellulose-decomposing organisms from bacteria to higher animals and plants have been employed as research targets. Termites, as one group of such interested cellulolytic life-forms, are important decomposers of cellulosic materials in tropical and subtropical regions (Yamada et al., 2005). In termite species harboring cellulolytic intestinal flagellates (species except family Termitidae), endogenous (termite-own) enzymes and those from symbiotic flagellates shared roles in cellulose digestion, and each element produced different enzymes in the cellulolytic function (Nakashima et al., 2002a, b; Watanabe et al., 2002).

In cellulose digestion, it is generally accepted that three different enzymes termed cellobiohydrolase (EC 3.2.1.91), endo- $\beta$-1,4-glucanase (EC
3.2.1.4) and $\beta$-glucosidase (EC 3.2.1.21) play a synergistic role in converting insoluble cellulose to glucose (Beguin and Aubert, 1994). The endogenous cellulolytic enzymes of termites primarily consist of endo- $\beta$-1,4-glucanase and $\beta$-glucosidase (Tokuda et al., 1997, 2002; Watanabe et al., 1997). So far, endogenous endo- $\beta$-1,4-glucanases of termites have been extensively studied (Tokuda et al., 1997; Watanabe et al., 1997, 1998). By contrast, biochemical and molecular biological studies on $\beta$ glucosidase of termites are limited. $\beta$-Glucosidase is a critical enzyme for cellulose degradation, catalyzing hydrolysis of cellobiose or cello-oligomers to glucose. Among the flagellate-harboring termites, only Neotermes koshunensis has been used for purification of the endogenous $\beta$-glucosidase that is secreted in the salivary glands (Tokuda et al., 2002). However, since the endogenous $\beta$-glucosidase from $N$. koshunensis was characterized using the partially purified enzyme (Tokuda et al., 2002), the real property of this enzyme still re-

\footnotetext{
* To whom correspondence should be addressed at: E-mail: hinabe@affrc.go.jp DOI: 10.1303/aez.2007.457
} 
mains to be elucidated. Purification of digestive enzymes in insects is often inefficient and time-consuming due to their small body sizes and limited availability of the samples, and thus heterologous overexpression using a simple vector-host system would be a powerful tool for characterization and further applications of such enzymes. In the present study we describe the expression and enzymatic characterization of digestive $\beta$-glucosidase from the termite, $N$. koshunensis.

\section{MATERIALS AND METHODS}

Insect. Neotermes koshunensis (Isoptera, Kalotermitidae), which are distributed in the subtropical region of Japan, were collected and maintained as previously described (Tokuda et al., 2002).

Bacterial strains, plasmids, and culture conditions. A plasmid vector $\mathrm{pAD} 10 \alpha$, which was constructed as previously described (Ni et al., 2005), was employed as a cloning vector for $E$. coli DH5 $\alpha$ (Toyobo, Osaka, Japan). Overexpression was conducted using the pQE30 vector (Qiagen, Inc., Valencia, CA, USA) with E. coli JM109 (Toyobo) as the host cell. E. coli cells harboring the pQE30 plasmids were grown at $37^{\circ} \mathrm{C}$ in Luria broth (LB) medium supplemented with $100 \mu \mathrm{g} / \mathrm{ml}$ of ampicillin. For enzyme production, E. coli cells were grown overnight in $\mathrm{LB}$ medium at $37^{\circ} \mathrm{C}$. An aliquot $(100 \mu \mathrm{l})$ of the pre-cultured cells was added to $10 \mathrm{ml}$ of $\mathrm{LB}$ medium and incubated at $37^{\circ} \mathrm{C}$ with continuous shaking until the absorbance at $600 \mathrm{~nm}$ reached to 1.0. Then, isopropyl- $\beta$-D-thiogalactopyranoside (IPTG; final concentration, $1 \mathrm{mM}$ ) was added to induce expression and the cells were grown at $26^{\circ} \mathrm{C}$ for $4 \mathrm{~h}$ with continuous shaking.

Preparation of $\beta$-glucosidase cDNA from $N$. koshunensis and subcloned into expression vector. The $\beta$-glucosidase cDNA from $N$. koshunensis (NkBG: AB073638) was obtained according to the methods described previously (Tokuda et al., 2002). The cDNA fragment of the open reading frame (without the sequence encoding the N-terminal signal peptide) was cloned into pAD $10 \alpha$ vector. Two primers pQEBGFor (5' GCT AAA GAA GAA GGG GGA TCC CTC GAG AAA AGA GAC GTA GCC TCC 3'; The underline indicates the BamHI site) and pQEBGRev (5' TTG TTC

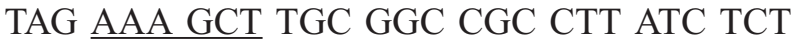

GAA GCG CTC AGG 3'; The underline indicates the HindIII site) were designed to amplify the inserted DNA fragment from the $N k B G$-pAD $10 \alpha$. The amplified fragment was double digested with BamHI and HindIII and ligated with the pQE 30 vector. The plasmid was then transformed into $E$. coli JM109 and cultured as mentioned above.

Preparation of crude bacterial extracts and purification. After expression, the bacterial cells were recovered by centrifugation and the pellets were lysed using CelLytic ${ }^{\mathrm{TM}}$ B Cell Lysis Reagent (Sigma-Aldrich, St. Louis, MO, USA). The supernatants were recovered and are referred to as crude extracts. The recombinant enzyme was purified from the crude extracts using the MagExtract Histag fusion protein purification kit (Toyobo) according to the manufacturer's instruction. Enzyme purity was assessed by SDS-PAGE, which was performed using Ready Gel E-R520L (5-20\% gradient; ATTO, Japan). Broad range prestained SDSPAGE standards (Bio-Rad, Hercules, CA, USA) were used as the molecular weight markers.

Enzyme and protein assays. $\beta$-Glucosidase activity was measured using cellobiose (Nakalai Tesque, Kyoto, Japan) as the substrate. An aliquot $(25 \mu \mathrm{l})$ of the enzyme solution was added into $100 \mu \mathrm{l}$ of $2 \%$ cellobiose $(\mathrm{w} / \mathrm{v})$ in $0.1 \mathrm{M}$ sodium acetate buffer $(\mathrm{pH} 5.5)$. The reaction mixture was then incubated at $37^{\circ} \mathrm{C}$ for $5 \mathrm{~min}$ and liberated glucose was detected by adding $1 \mathrm{ml}$ of the glucose oxidase-mutarotase reagent (Glucose CII Test Wako; Wako Pure Chemical Co., Tokyo, Japan). The amount of glucose produced was determined by measuring absorbance at $505 \mathrm{~nm}$. One unit (U) of enzyme activity was defined as the amount of enzyme which produced $1 \mu \mathrm{mol}$ of glucose per min. Protein concentrations were determined using Quick Start Bradford dye reagent (Bio-Rad) with bovine serum albumin as the standard. Western blotting was carried out as previously described (Sugimura et al., 2003) with the anti His-tag antibody that was conjugated with horseradish peroxidase (Qiagen).

Characterization of the recombinant $\beta$-glucosidase. Kinetic constants $\left(K_{\mathrm{m}}\right.$ and $\left.V_{\text {max }}\right)$ were determined using cellobiose varying from 1 to $20 \mathrm{~mm}$ in $0.1 \mathrm{M}$ sodium acetate buffer ( $\mathrm{pH}$ 5.5) on the basis of Lineweaver-Burk plot. The effect of temperature on the recombinant $\beta$-glucosidase activity was measured at 20 to $75^{\circ} \mathrm{C}$ with $5^{\circ} \mathrm{C}$ intervals. Ther- 
mostability was determined by measuring the residual enzyme activity after pre-incubation of the diluted enzyme for $30 \mathrm{~min}$ at 20 to $75^{\circ} \mathrm{C}$ at $5^{\circ} \mathrm{C}$ intervals. The effect of $\mathrm{pH}$ was analyzed with McIlvaine's buffer (di-sodium phosphate-citric acid) (McIlvaine, 1921) ranging from $\mathrm{pH} 3.0$ to 9.0 at 0.5 intervals. For $\mathrm{pH}$ stability, the enzyme was preincubated at $\mathrm{pH} 3.0-9.0$ at 0.5 intervals at ambient temperature for $30 \mathrm{~min}$. After enzymatic reactions, the enzymatic activities were measured as aforementioned.

Substrate specificities. Substrates for the experiments were purchased from Sigma-Aldrich unless otherwise indicated. To analyze substrate specificity, $\beta$-glucosidase activity was determined by measuring the release of glucose from various substrate solutions and suspensions (in $2 \%[\mathrm{w} / \mathrm{v}]$ in $0.1 \mathrm{M}$ sodium acetate buffer [pH 5.5] unless specially mentioned). The substrate used for the specificity test were: gentibiose, melibiose, palatinose, sophorose, lactose, laminarin, salicin, cellulose (sodium carboxymethylcellulose, 1\%, w/v), laminaribiose (Seikagaku Corp., Tokyo, Japan), cellotriose (30 mm, Nakalai Tesque), cellotetraose (30 mm, Nakalai Tesque), and cellopentose (15 mM, Nakalai Tesque). The condition of the enzymatic assays was the same as the quantitative assay aforementioned with cellobiose. $\beta$-Glucosidase activity was also determined by measuring the release of $p$ nitrophenol from $10 \mathrm{~mm} p$-nitrophenyl- $\beta$-D-glucoside (glucopyranoside) ( $p$ NP $\beta$ Glu) (Nakalai), $10 \mathrm{~mm} p$-nitrophenyl- $\beta$-D-galactopyranoside $(p \mathrm{NP} \beta \mathrm{Gal}), \quad 10 \mathrm{~mm} \quad p$-nitrophenyl- $\beta$-D-fucopyranoside ( $p \mathrm{NP} \beta \mathrm{Fuc})$, or $p$-nitrophenyl- $\beta$-D-mannopyranoside $(p \mathrm{NP} \beta \mathrm{Man})$ in $0.1 \mathrm{M}$ sodium acetate buffer (pH 5.5) as described by Inoue et al. (2005). For the $p$-nitrophenyl compounds, $25 \mu 1$ of enzyme were added into $100 \mu \mathrm{l}$ of the substrate solution and incubated for $5 \mathrm{~min}$ at $37^{\circ} \mathrm{C}$. The reaction was terminated by addition of $1 \mathrm{ml}$ of $0.6 \mathrm{M} \mathrm{Na}_{2} \mathrm{CO}_{3}$ solution and the amount of $p$-nitrophenol librated was measured by the absorbance at $410 \mathrm{~nm}$. One unit of enzyme activity was defined as the amount of enzyme that produced $1 \mu \mathrm{mol}$ of released $p$-nitrophenol per min.

\section{RESULTS}

Overexpression of the $\beta$-glucosidase gene and purification of the enzyme

The endogenous $\beta$-glucosidase cDNA of $N$. koshunensis was cloned into pQE30 and successfully overexpressed in E. coli JM109. The homogeneous protein band corresponding to the molecular weight of $60 \mathrm{kDa}$ was observed after the His-tagbased affinity purification from the cell free crude extract (Fig. 1a). Western blot analysis using anti His-tags antibody confirmed that the inserted $\beta$ glucosidase cDNA was overexpressed in $E$. coli (Fig. 1b). Table 1 summarizes the purification results of the recombinant $\beta$-glucosidase. The expressed protein had apparent $\beta$-glucosidase activity and was purified to 6.4 fold from the crude extracts with $20 \%$ recovery. Approximately $0.1 \mathrm{mg}$ of the purified enzyme was obtained from $10 \mathrm{ml}$ of cell culture.

\section{Characterization of the purified recombinant $\beta$ - glucosidase}

Table 2 shows the comparison of the recombinant $\beta$-glucosidase with the partially purified $\beta$ -

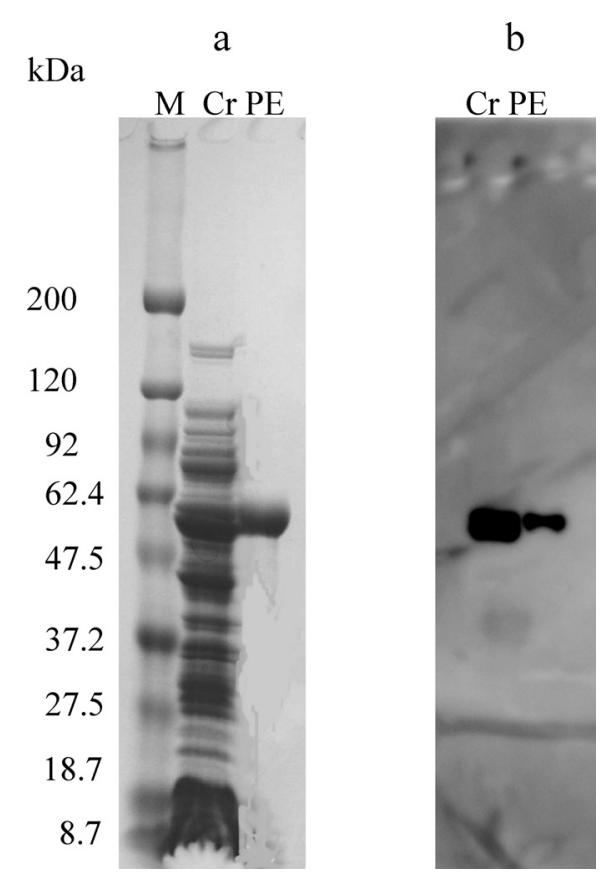

Fig. 1. Overexpression of $N k B G$ in E. coli JM109. (a) SDS-PAGE analysis of the expression of the $\beta$-glucosidase, (b) Western blot analysis using anti His-tag antibody. M: molecular weight markers; lane Cr: crude extract; PE: purified recombinant enzyme (NkBG). 
Table 1. Purification of the recombinant $\beta$-glucosidase from $E$. coli

\begin{tabular}{cccccc}
\hline \multicolumn{1}{c}{ Step } & $\begin{array}{c}\text { Total protein } \\
(\mathrm{mg})\end{array}$ & $\begin{array}{c}\text { Total activity } \\
(\mathrm{U})\end{array}$ & $\begin{array}{c}\text { Specific activity } \\
(\mathrm{U} / \mathrm{mg})\end{array}$ & $\begin{array}{c}\text { Recovery } \\
(\%)\end{array}$ & $\begin{array}{c}\text { Purification } \\
(\text { fold })\end{array}$ \\
\hline Crude extract & 3.13 & 76.7 & 24.5 & 100 & 1 \\
Purified enzyme & 0.095 & 15.57 & 156.7 & 19.9 & 6.4 \\
\hline
\end{tabular}

One unit $(\mathrm{U})$ is the amount of enzyme which produced $1 \mu \mathrm{mol}$ of glucose/min.

Table 2. Comparison of the native termite salivary and recombinant $\beta$-glucosidases ${ }^{\mathrm{a}}$

\begin{tabular}{lcccccc}
\hline \multicolumn{1}{c}{ Enzymes } & $\begin{array}{c}\text { Specific } \\
\text { activity } \\
(\mathrm{U} / \mathrm{mg})\end{array}$ & $\begin{array}{c}K_{\mathrm{m}} \\
\text { value } \\
(\mathrm{mm})\end{array}$ & $\begin{array}{c}V_{\max } \\
\text { value } \\
(\mathrm{U} / \mathrm{mg})\end{array}$ & $\begin{array}{c}\text { Optimal } \\
\text { temperature } \\
\left({ }^{\circ} \mathrm{C}\right)\end{array}$ & $\begin{array}{c}\text { Thermostability } \\
\left({ }^{\circ} \mathrm{C}\right)\end{array}$ & $\begin{array}{c}\text { Optimal } \\
\mathrm{pH}\end{array}$ \\
\hline Salivary $\beta$-glucosidase & 55.3 & 2.5 & nd & nd & $\sim 45$ & 5.6 \\
Recombinant $\beta$-glucosidase & 156.7 & 3.8 & 220 & 50 & $\sim 45$ & 5.0 \\
\hline
\end{tabular}

${ }^{a}$ Values shown are the means of triplicate experiments with cellobiose as substrates.

${ }^{\mathrm{b}}$ Data reported by Tokuda et al. (2002). nd: not determined.

a)

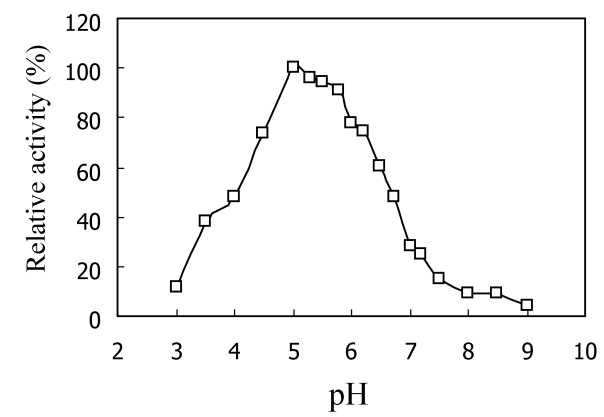

c)

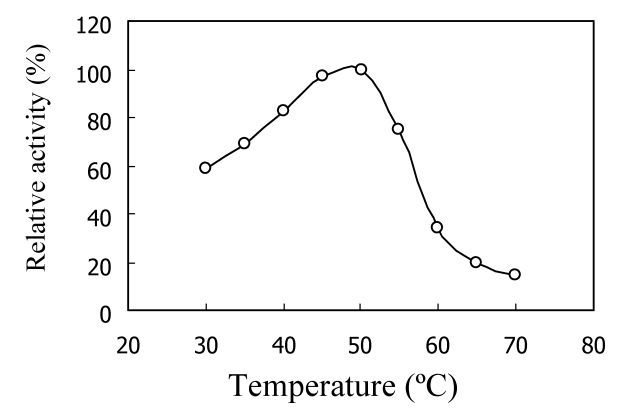

b)

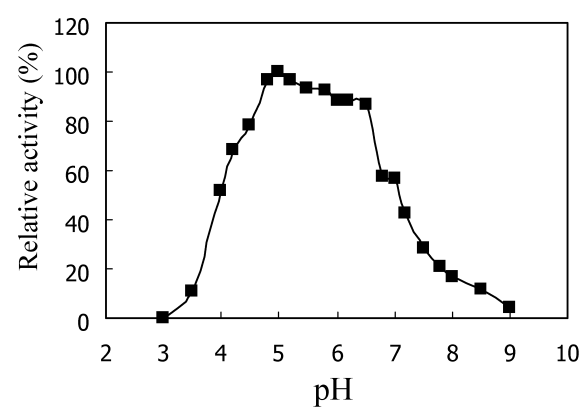

d)

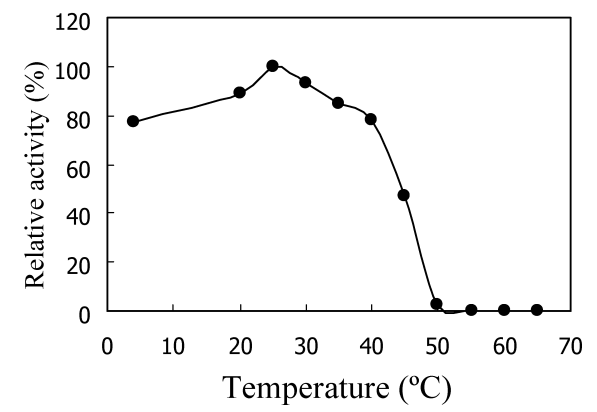

Fig. 2. Effects of $\mathrm{pH}$ and temperature on the recombinant $\beta$-glucosidase activity and stability of the recombinant termite $\beta$ glucosidase. (a) Effect of $\mathrm{pH}$ on the $\beta$-glucosidase activity. (b) Effect of $\mathrm{pH}$ on the enzyme stability. (c) Effect of temperature on the $\beta$-glucosidase activity. (d) Effect of temperature on the stability. The relative activities are shown as the means of at least three measurements.

glucosidase from the salivary glands of $N$. koshunensis (Tokuda et al., 2002). The recombinant enzyme exhibited $\mathrm{pH}$ optimal at 5.0, and was stable (i.e. retaining over $50 \%$ of the maximal activity) from $\mathrm{pH} 4$ to 7 (Fig. 2a and b). The same enzyme showed maximum activity at $50^{\circ} \mathrm{C}$ in the re- 
action for $5 \mathrm{~min}$, and retained the activity above $80 \%$ of the maximum value during the preincubations at $40^{\circ} \mathrm{C}$ and below for $30 \mathrm{~min}$, but almost completely lost activity at $50^{\circ} \mathrm{C}$ (Fig. $2 \mathrm{c}$ and d). The specific activity of the purified recombinant $\beta$ glucosidase against cellobiose was $156.7 \mathrm{U} / \mathrm{mg}$, which is about three times higher than that of salivary $\beta$-glucosidase partially purified from $N$. koshunensis (55.3 U/mg; Tokuda et al., 2002). The $K_{\mathrm{m}}$ and $V_{\max }$ for cellobiose were $3.8 \mathrm{~mm}$ and $220 \mathrm{U} / \mathrm{mg}$, respectively (Table 2).

\section{Substrate specificities}

Among the substrates tested, the recombinant $\beta$ glucosidase exhibited the maximal activity against laminaribiose. When cellobiose was used as the substrate, it showed $80 \%$ of activity as compared with laminaribiose. The recombinant $\beta$-glucosidase also hydrolyzed cellotriose and cellotetraose to some extent, and weakly degraded lactose and laminarin (Fig. 3a). No activity was observed against other natural compounds used as substrates (Fig. $3 a)$. Among the five synthetic chromogenic substrates, the recombinant $\beta$-glucosidase showed the maximal activity against $p \mathrm{NP} \beta$ Fuc $(66.5 \mathrm{U} / \mathrm{mg})$, and the activity against $p \mathrm{NP} \beta$ Glu was about $20 \%$ of the activity against $p \mathrm{NP} \beta$ Fuc (Fig. 3b). Compared with the activity against cellobiose (156.7 $\mathrm{U} / \mathrm{mg}$ ), the purified recombinant enzyme showed considerably lower activity against the synthetic analog $p \mathrm{NP} \beta \mathrm{Glu}(13.6 \mathrm{U} / \mathrm{mg})$. The enzyme showed weak activity against $p \mathrm{NP} \beta \mathrm{Gal}$, and it did not hydrolyze $p \mathrm{NP} \beta$ Man and $p \mathrm{NP} \beta \mathrm{Xyl}$ (Fig. 3b).

\section{DISCUSSION}

The present study showed the successful overexpression of termite $\beta$-glucosidase in $E$. coli. Although a number of microbial $\beta$-glucosidase genes have been expressed in either $E$. coli, yeast or fungi (Pandey and Mishra, 1997; Saloheimo et al., 2002; Li et al., 2004; Hong et al., 2007) studies on heterologous expressions of insect $\beta$-glucosidases are still limited (Marana et al., 2002; Byeon et al., 2005).

The enzymatic properties and substrate specificities of the expressed $\beta$-glucosidase were mostly consistent with those of the native $\beta$-glucosidase from the salivary glands of $N$. koshunensis (Tokuda et al., 2002). As is the case of the partially purified a)

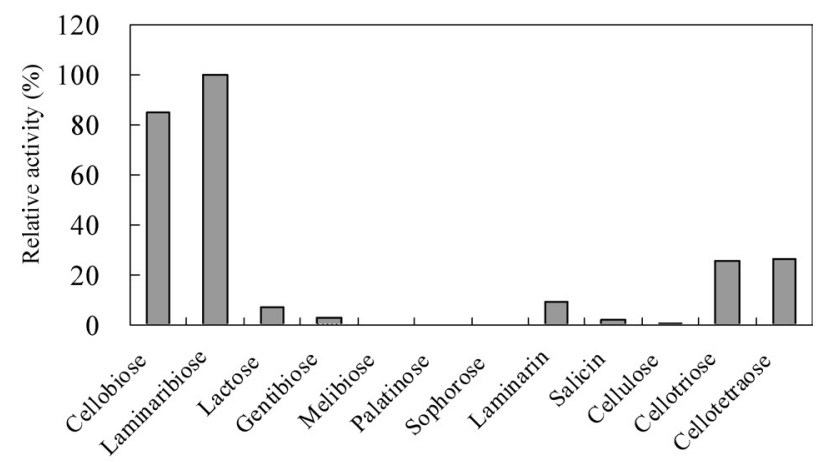

b)

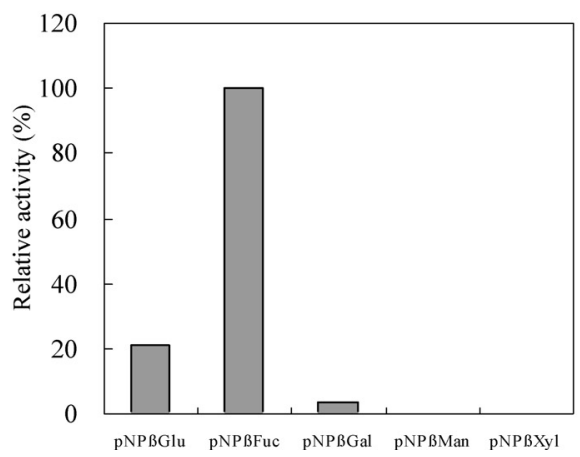

Fig. 3. Substrate specificities of the recombinant $\beta$-glucosidase against natural substrates (a) and synthetic substrates (b). Relative activities are shown as the means of three assays, which were calculated in comparison with the activities against laminaribiose $(186.4 \mathrm{U} / \mathrm{mg}$; a) or $p \mathrm{NP} \beta$ Fuc $(66.5$ $\mathrm{U} / \mathrm{mg}$; b) (shown as 100\%).

$\beta$-glucosidase, this enzyme preferentially hydrolyzes $\beta-1,3$ glycosidic bonds in addition to $\beta$ 1,4 glycosidic linkages because of the strong activity against laminaribiose. The recombinant $\beta$-glucosidase also hydrolyzed $p$-nitrophenolic compounds to some extent, confirming that the termite $\beta$-glucosidase is affiliated with Class 1 enzymes, which hydrolyze both native and synthetic substrates (Terra et al., 1996). The present study employed cellotriose and cellotetraose as short cellulosic substrates in addition to cellobiose, and the recombinant enzyme showed more active hydrolysis of cellobiose than cellotriose or cellotetraose. Since the endogenous endo- $\beta-1,4$-glucanases of termites are able to hydrolyze cello-oligosaccharides (Tokuda et al., 1997; Watanabe et al., 1997), the present $\beta$-glucosidase would primarily partici- 
pate in cleavage of cellobiose or some other hemicellulosic disaccharides to produce glucose. However, its inactiveness against $p \mathrm{NP} \beta \mathrm{Xyn}$ suggests that the termite $\beta$-glucosidase is not involved in degradation of the major hemicellulosic compounds such as xylan and its derivatives.

As previously reported, the present $\beta$-glucosidase has a potential $\mathrm{N}$-glycosylation site near the C-terminus (Tokuda et al., 2002). Considering the consistency in the molecular weights and the enzymatic properties between the recombinant $\beta$-glucosidase of the current study and the partially purified (native) $\beta$-glucosidase from the salivary glands of $N$. koshunensis (Tokuda et al., 2002), the latter is likely functional without glycosylation in vivo. However, it is noteworthy that there are a few small differences in enzymatic properties between the recombinant and the native $\beta$-glucosidases. The recombinant enzyme revealed threefold higher specific activity than that of the native enzyme (Tokuda et al., 2002). This difference might be caused by impurity of the native enzyme, and the $V_{\max }$ value of the recombinant $\beta$-glucosidases would reflect the real property of the catalytic velocity of the salivary $\beta$-glucosidase of $N$. koshunensis.

In the previous paper, we showed a mass-production system of termite endo- $\beta$-1,4-glucanases using the same vector-host combination as described in the present study (Ni et al., 2005). The present result provokes expectations for further exploration and characterization of $\beta$-glucosidases not only in flagellate-harboring termites but also in flagellate-free termites that have diverse feeding preferences (Waller and Fage, 1987). Furthermore, an accumulation of DNA sequence data of the termite enzymes will provide an opportunity for improvement of the $\beta$-glucosidase properties using bioengineering methods such as DNA shuffling like the case of the termite endo- $\beta$-1,4-glucanases (Ni et al., 2005), which enables modifications of the enzymes of insect origins to be adequate for industrial applications or biomass conversions.

\section{ACKNOWLEDGEMENTS}

This work was supported by the Insect Technology Project of the Ministry of Agriculture, Forestry and Fisheries of Japan (Apr. 1st, 2003-Mar. 31st, 2007) to H. W. J. N. contributed to this study as a JSPS (Japan Society for the Promotion of Science) fellow in NIAS from Sep. 13th, 2004-Sep. 12th, 2006. G. T. was also supported by the visiting research and the $21 \mathrm{st}$
COE programs of University of the Ryukyus.

\section{REFERENCES}

Beguin, P. and J.-P. Aubert (1994) The biological degradation of cellulose. FEMS Microbiol. Rev. 13: 25-58.

Byeon, G. M., K. S. Lee, Z. Z. Gui, I. Kim, P. D. Kang, S. M. Lee, H. D. Sohn and B. R. Jin (2005) A digestive betaglucosidase from the silkworm, Bombyx mori: cDNA cloning, expression and enzymatic characterization. Comp. Biochem. Physiol. B Biochem. Mol. Biol. 141: 418-427.

Hong, J., H. Tamaki and H. Kumagai (2007) Cloning and functional expression of thermostable beta-glucosidase gene from Thermoascus aurantiacus. Appl. Microbiol. Biotechnol. 73: 1331-1339.

Inoue, T., S. Moriya, M. Ohkuma and T. Kudo (2005) Molecular cloning and characterization of a cellulase gene from a symbiotic protist of the lower termite, Coptotermes formosanus. Gene 349: 67-75.

Li, X. L., L. G. Ljungdahl, E. A. Ximenes, H. Chen, C. R. Felix, M. A. Cotta and B. S. Dien (2004) Properties of a recombinant beta-glucosidase from polycentric anaerobic fungus Orpinomyces PC-2 and its application for cellulose hydrolysis. Appl. Biochem. Biotechnol. 113-116: 233-250.

Marana, S. R., W. R. Terra and C. Ferreira (2002) The role of amino-acid residues Q39 and E451 in the determination of substrate specificity of the Spodoptera frugiperda betaglycosidase. Eur. J. Biochem. 269: 3705-3714.

Mcllvaine, T. C. (1921) A buffer solution for colorimetric comparison. J. Biol. Chem. 49: 183-186.

Nakashima, K., H. Watanabe, H. Saitoh, G. Tokuda and J. I. Azuma (2002a) Dual cellulose-digesting system of the wood-feeding termite, Coptotermes formosanus Shiraki. Insect. Biochem. Mol. Biol. 32: 777-784.

Nakashima, K., H. Watanabe and J. I. Azuma (2002b) Cellulase genes from the parabasalian symbiont Pseudotrichonympha grassii in the hindgut of the wood-feeding termite Coptotermes formosanus. Cell. Mol. Life Sci. 59: 1554-1560.

Ni, J., M. Takehara and H. Watanabe (2005) Heterologous overexpression of a mutant termite cellulase gene in Escherichia coli by DNA shuffling of four orthologous parental cDNAs. Biosci. Biotechnol. Biochem. 69: 1711-1720.

Pandey, M. and S. Mishra (1997) Expression and characterization of Pichia etchellsii beta-glucosidase in Escherichia coli. Gene 190: 45-51.

Saloheimo, M., J. Kuja-Panula, E. Ylosmaki, M. Ward and M. Penttila (2002) Enzymatic properties and intracellular localization of the novel Trichoderma reesei beta-glucosidase BGLII (cel1A). Appl. Environ. Microbiol. 68: 4546-4553.

Sugimura, M., H. Watanabe, N. Lo and H. Saito (2003) Purification, characterization, cDNA cloning and nucleotide sequencing of a cellulase from the yellow-spotted longicorn beetle, Psacothea hilaris. Eur. J. Biochem. 270: 3455-3460.

Terra, W. R., C. Ferreira, B. P. Jordao and R. J. Dillon (1996) 
Digestive enzymes. In Biology of the Insect Midgut (M. J. Lehane and P. F. Billingsley eds.). Chapman \& Hall, London, pp. 153-194.

Tokuda, G., H. Watanabe, T. Matsumoto and H. Noda (1997) Cellulose digestion in the wood-eating higher termite, Nasutitermes takasagoensis (Shiraki): distribution of cellulases and properties of endo-beta-1,4-glucanase. Zool. Sci. 14: 83-93.

Tokuda, G., H. Saito and H. Watanabe (2002) A digestive beta-glucosidase from the salivary glands of the termite, Neotermes koshunensis (Shiraki): distribution, characterization and isolation of its precursor cDNA by $5^{\prime}-$ and $3^{\prime}-$ RACE amplifications with degenerate primers. Insect. Biochem. Mol. Biol. 32: 1681-1689.

Waller, D. A. and J. P. L. Fage (1987) Nutritional ecology of termites. In Nutritional Ecology of Insects (F. J. Slansky and J. G. Rodriguez eds.). Wiley-Interscience, New York, pp. 487-532.
Watanabe, H., M. Nakamura, G. Tokuda, I. Yamaoka, A. M. Scrivener and H. Noda (1997) Site of secretion and properties of endogenous endo-beta-1,4-glucanase components from Reticulitermes speratus (Kolbe), a Japanese subterranean termite. Insect Biochem. Mol. Biol. 27: 305-313.

Watanabe, H., H. Noda, G. Tokuda and N. Lo (1998) A cellulase gene of termite origin. Nature 394: 330-331.

Watanabe, H., K. Nakashima, H. Saito and M. Slaytor (2002) New endo-beta-1,4-glucanases from the parabasalian symbionts, Pseudotrichonympha grassii and Holomastigotoides mirabile of Coptotermes termites. Cell. Mol. Life Sci. 59: 1983-1992.

Yamada, A., T. Inoue, D. Wiwatwitaya, M. Ohkuma, T. Kudo, T. Abe and A. Sugimoto (2005) Carbon mineralization by termites in tropical forests, with emphasis on fungus combs. Ecol. Res. 20: 453-460. 